\title{
Smart Marketing Usage in Egyptian Domestic Tourism: Opportunities and Challenges
}

\author{
Maged G. Briez ${ }^{\mathrm{a}}$ \\ , Sabreen G. Abd Eljalil ${ }^{\mathrm{b}}$, \\ Mohamed Ezzat Mohamed ${ }^{\mathrm{c}}$, \\ ${ }^{a}$ Ph.D. Researcher, Faculty of Tourism and Hotels, Minia University \\ ${ }^{b}$ Professor, Faculty of Tourism and Hotels, Luxor University, Egypt \\ ${ }^{c}$ Associate Professor, Faculty of Tourism and Hotels, Minia University, Egypt
}

\section{Keywords}

Challenges

Domestic Tourism

Egypt

Opportunities

Smart Marketing

\begin{abstract}
Smart marketing has a large number of methods such as websites, search engines, social media sites, mobile apps, videos, etc. which play a vital role in enhancing the relationship between travel agency and tourists. Therefore, this study aims to identify the Smart Marketing Methods and explore the opportunities and challenges of using smart marketing methods in domestic tourism in Egypt. Accordingly, it adapted the descriptive methodology and used a mixed approach in collecting quantitative and qualitative. The quantitative approach is used by employing questionnaire to gather the primary data from domestic tourists in Egypt. The qualitative method is represented in semi-structured interviews with Top Ten Travel Agencies representatives in Egypt. The main results of study demonstrated that there are many advantages of using smart marketing methods in domestic tourism in Egypt; however, there are some obstacles that have clear impacts upon them. The study recommends that Travel Agencies and Tourism Associations in Egypt should apply formal platform to promote domestic tourism and improve their marketing strategy to take advantages of using Smart marketing methods in tourism.
\end{abstract}




\section{Introduction}

The revolution of Information Communication and Technology (ICT) has enabled tourists to search for destinations worldwide more easily. An increasing number of consumers worldwide are no longer dependent on travel agencies to look for information and inspiration for their next holiday. Instead, consumers make use of the Internet, and browse online for inspiration about their potential next holiday destination (ETC, 2012), which facilitates consumers' decision-making process. However, many destinations worldwide struggle with this process as their Internet and online presence might still be quite basic (Buhalis, 2000). Moreover, with increased attention paid to "Smart" as a concept arises interest in and application of the term across different fields. The buzzword is a technology-oriented term and it is often used as a prefix implying specific technological characteristics which are connectivity and intelligence (Gretzel, Werthner, Koo, \& Lamsfus, 2015). The word can be defined originally as resource optimization based on the utilization of information and communication technologies (ICT) (Gretzel et al., 2015; Werthner et al., 2015). As the concept applies to various areas, it has also made its way into tourism, resulting in Smart tourism and the use of Smart technologies in travelrelated activities and experiences (Gretzel et al., 2015; Hunter, Chung, Gretzel, \& Koo, 2015).

The Smart concept has long ago migrated from mobile devices to places (e.g. Smart Cities). Smart places have arisen from the impact of new and modern technologies on the spaces we live in, including cities, regions and countries (Hedlund, 2012; Zygiaris, 2013; Vanolo, 2014).

There are several researchers who study the influences of ICTs Marketing Methods in international tourism sector in Egypt (e.g., Abdelhamid, 2010; Shehawy, 2010; Mohamed. 2015), but they didn't investigate the Domestic Tourism market in their studies. Therefore, this study sheds light on the impact of Smart marketing on the Egyptian tourism in general and aims to achieve several specified objectives related to Domestic tourism in particular. These include: 1) Identifying the Smart marketing methods; 2) Exploring advantages and disadvantages of using Smart marketing methods in Domestic Tourism; 3) Determining the challenges or obstacles facing the use of Smart Marketing methods in Domestic Tourism in Egypt.

\section{Literature Review}

\subsection{Smart Technology}

The concept of "Smart" generally can be defined as an individual's mental ability, having or showing quick intelligence or ready mental capability. When applied to a device, it means that it is controlled by a computer, so that it appears to act in an intelligent way (Oxford Learners Dictionaries online, 2019; Dictionary online, 2019).

The Smart concept has arisen as a result of the development of Information and Communications Technology and the need for sustainability (Nam and Pardo, 2011; Gretzel, et al., 2015; Gajdošík, 2018). Additionally, it mainly describes the technological, economic and social developments enabled by technologies that based on integration of hardware, software and network technologies (included sensors, big data, open data, new ways of connectivity) to help people make more intelligent decisions about alternatives through optimizing the use of resources (Washburn et al., 2010; Harrison et al., 2010). 
Gretzel, et al. (2015, p. 42) defined the Smart technology as "a summary term for specific technologies and technology-driven phenomena that provide data and connectivity in ways that were not possible before. Sensor technology lies at the heart of smart technology but ubiquitous Wi-Fi, near-field communication (NFC), smart phones/mobile connectivity, radio-frequency identification (RFID) and sophisticated data warehouses and data mining algorithms are also considered vital to creating a smart technology infrastructure". The developments of Smart technology tools as marketing tools in the following Fig.1.

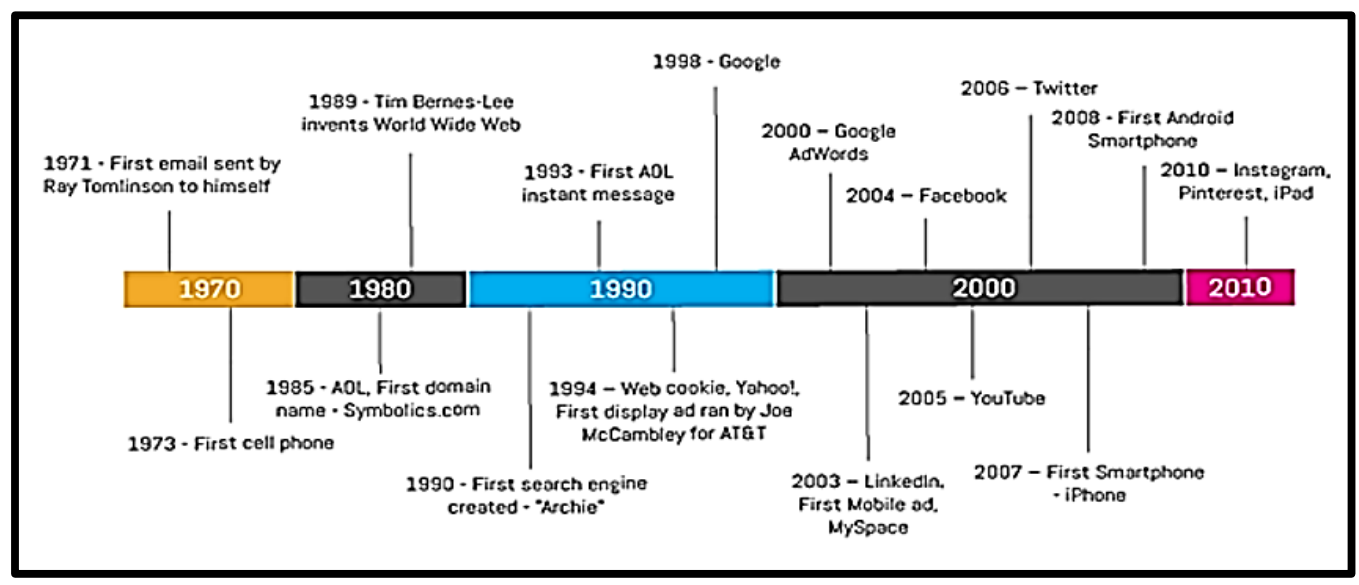

Figure (1): The Digital and Smart Marketing Tools Evolution, Malik (2017, p. 715)

\subsection{Smart Marketing and Tourism}

Many reviews have revealed that the Smart term has been one of buzzwords used in many aspects of life such as; Smart city, Smart building, Smart product, Smart services, Smart tourism, etc. they have implied the synonym of Smart term such as "digital, internet, online" (Gutiérrez, Garbajosa, Díaz, \& Yague, 2013; Gretzel et al., 2015; Marquardt, 2017). Moreover, Gretzel et.al, (2015) indicated that as everything has evolved into Smart; the need for conceptualization on this phenomenon has been increased. As well as, Boes, Buhalis, \& Inversini (2015, p.391) stated that; the term 'Smart' represents a marketing word for all things that are embedded or enhanced by technology"

Despite the lack of specified definition of 'Smart Marketing', many researchers used it as an alternative of digital marketing (Baglione, 2014; Daszkiewicz, 2015; Kalra, Kumar, Batra, \& Namrata, 2017; Simões, Barbosa, \& Filipe, 2019). Simões et al. $(2019$, p.2) referred to smart marketing concept in his articles as; "Nowadays a new wave of Internet-connected technologies is gaining steam: The Internet of Things (IoT). IoT gives rise to several methods at level of augmented reality, wearable technology, chatbots, gamification, transmedia, and others that impact on smart marketing"

Hence, it is clear that 'Smart marketing' includes all digital marketing tools (Internet, Social network, Mobile, Augmented reality, Wearable Technology). In Smart and Digital era there are many influences in the tourism industry and marketing field. The smart technologies developments have offered multiple uses for marketing purposes. Moreover, they have enabled tourists and tour operators to change the way of conducting exchanges, which have been the core of all marketing transactions (Hanson, 2000). The Smart and digital Marketing Mix (MM), which has included eproduct, e-price, e-place, e-promotion, e-process, e-people, and e-physical evidence, is considered a powerful tool in global tourism marketing management revolution 
Matura (2018). According to (Law, Buhalis, \& Cobanoglu, 2014) the tourism industry has a high dependency on ICTs. Therefore, it is normal to see the concept of "Smart" being applied to tourism, so the concept of 'Smart tourism' describes the influence of ICTs development upon tourism development at current stage. Likewise, there are many national policies that have adopted Smart tourism as a strategic plan of tourism development Such as; (best practices in Western Europe and Asia) (Gajdosik, 2018). Therefore, the modern marketing strategies should base on Smart technology tools.

\subsection{Characteristics of Smart Digital Marketing Campaigns}

In this regard, Kaur (2017) mentioned that there are top six characteristics of successful Smart digital marketing campaigns as follows:

1. Quality Website: a quality website today is important element before developing a business online. It helps your business extends geographical boundaries to reach newer customers, and also work as online destinations for your customers who can access it $24 \times 7$.

2. Strong Social Media Presence: social media platforms such as (Facebook, Twitter, LinkedIn, Instagram) enable stakeholders to reach out and speak directly to their audience. Social media platforms help brands to establish credibility, improve customer services and provide insights on what your customers are up to.

3. Search Engine Optimization SEO: is an essential part of Smart digital marketing. The online ranking of Tourism products on search engines (SE) defines the online popularity and helps increase visits of website .

4. Email Marketing: sending personalized emails to customers increases the chances of getting quick response along with showing that a travel agency cares .

5. Engaging Content: used across various online platforms should lead to increased engagement rates. Blogging is an excellent way to engage with audiences and move beyond than just selling products .

6. Mobile-Friendly: majority of online users today access the internet on their mobile phones and this should reflect in every aspect of online marketing considerations.

Fig.2 illustrates the most used tools or channels in tourism industry. These Tools are mentioned in previous studies that dealt with the relationship between Smart Technology and Tourism Industry. 


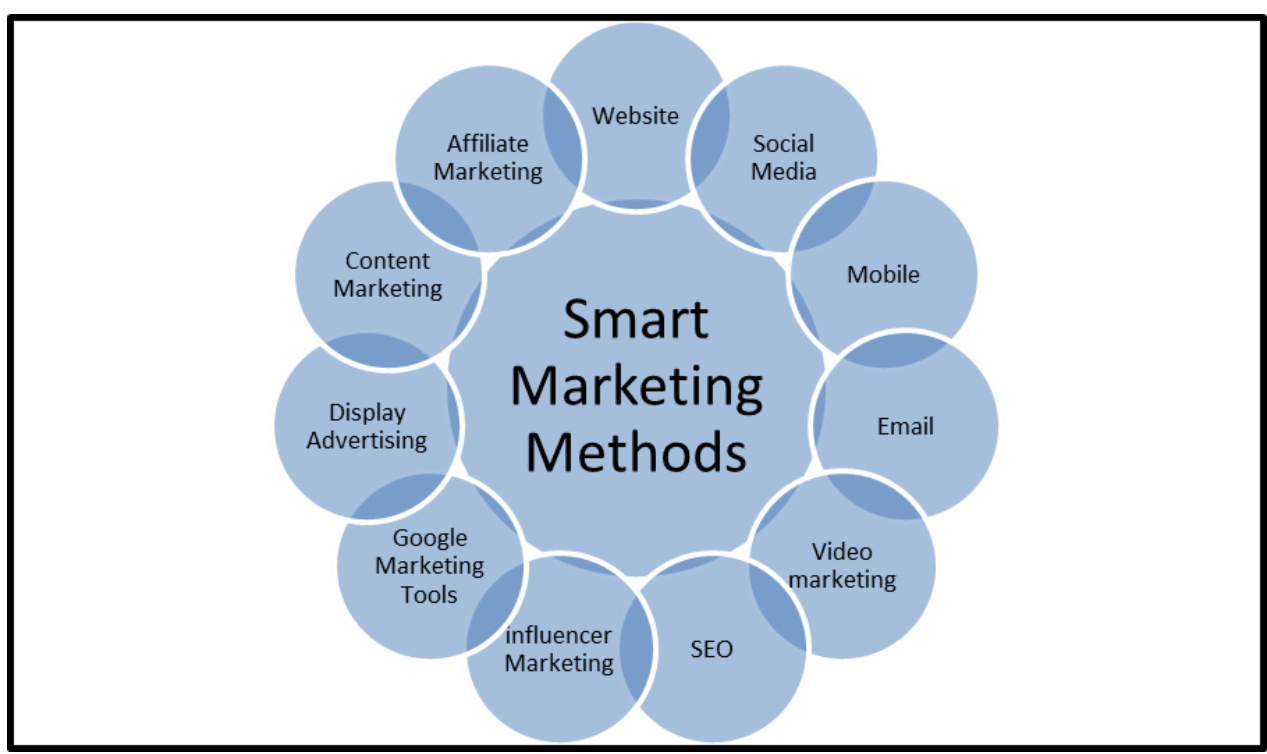

Figure (2): The Smart Marketing Methods, collected from (Buhalis, Licata, Cristina, \& Richer, 2002; Pan, Xiang, Law, \& Fesenmaier, 2011; Stokes, 2011; Rasty, Chou, \& Feiz, 2013; Guttormsdóttir, 2013; Mohamed, 2015; Gurjar, Kaurav \& Thakur, 2019; Kulwal, 2020)

The importance of Smart marketing application increased tremendously in the past few years. With a large share of people using Internet on a daily basis and the increasing consumers' purchases online, most companies have realized the necessity of practicing online marketing to survive the high level of competition. Smart marketing application makes it possible to reach a broad audience through different marketing channels such as websites, e-mail marketing, social media marketing, content marketing, Search Engine Marketing, Mobile Marketing, Video Marketing, affiliate marketing, Google advertising, and display marketing. Tourism and travel marketers should engage these methods in their marketing strategy (Buhalis \& Amaranggana, 2013).

\subsection{Advantages of using Smart marketing Methods in Tourism:}

There are several literature reviews that have identified the benefits of using Smart or Digital Marketing Methods in Tourism in general and in travel agencies in particular. Januszewska, Jaremen, and Nawrocka (2015) summarized these benefits as follows:

- Smart digital marketing methods have opened new pathways for relationships between the members of the distribution channels

- Offering easy real-time access to data and information

- Quick identification of consumer's needs and reaching potential clients with comprehensive, personalized and up-to-date information.

- Customization tourist services and products meeting individual needs.

- Making tourists more knowledgeable, demanding, empowered and active in planning, designing and specifying services and products.

- Improving the tourist service performance and quality

- Supporting travel agency to gain competitive advantage

- Decreasing transaction costs (of seeking information, distribution, promotion cost) and making higher revenues as possible. 
- Improving social inclusion for the tourists mobility (e.g. knowledge sharing about interesting places worth visiting, easy access, evaluation of accommodation facilities etc.)

- Providing sales analysis to monitor the increasingly frequent changes in demand .

- Speeding up management procedures and supporting efficient functioning of travel agencies.

\subsection{Domestic Tourism}

According to the world Tourism Organization (UNWTO) (2008, p.15) Domestic Tourism refers to "comprising the activities of a resident visitor within the country of reference, either as part of a domestic tourism trip or part of an outbound tourism trip". Moreover, Choo (2014, p. 1) defined Domestic Tourism as "tourism involving residents of one country traveling within their own country. It does not involve the crossing of international borders at entry points".

\subsection{Challenges of Domestic Tourism}

In general, the developing countries often face several challenges that limit the growth of this industry, so promoting Domestic Tourism in these countries usual has some of challenges that Mazimhaka, (2006) summarized as follows:

- The Domestic Tourism initiatives have usually been overshadowed by international tourism efforts .

- There are lacks of data regarding Domestic Tourism on a global scale .

- The absence of tourism culture which allows for an enthusiastic approach to travel by domestic people in developing countries.

- The lack of marketing strategies of Domestic Tourism in developing countries and the lack of long-term strategies in place, which leads to unsustainable growth.

- Most tourism marketing strategies are generally biased towards the development of international tourism, which is termed as the 'Northern Bias', which deters the creation of possible Domestic Tourism initiatives .

- While the importance of Domestic Tourism has been widely acknowledged, significant research and information on the current role of Domestic Tourism is still lacking .

- The most developing countries view Domestic Tourism as secondary to attracting the international market, which brings foreign currency. Therefore, there are very few records of Domestic Tourism initiatives .

- Unfortunately, many view tourism in developing countries as a luxury which many domestic people cannot afford.

- Economic adversity in developing countries makes them face difficulty in generating significant domestic tourists.

\subsection{Domestic Tourism in Egypt}

Domestic Tourism in Egypt represents an important part of the tourism industry, particularly with the declining number of international tourist arrivals. Whereas, the number of the international tourist arrivals have declined due to the political unrest since 2011 and pandemic of COVID-19 since 2019. Table.1 shows the effect of various crises on the returns from international tourism in Egypt from 2010 to 2020 . 
Table (1): the Effect of various crises on income from international tourism in Egypt (2010- 2020)

\begin{tabular}{|c|l|c|c|}
\hline Year & \multicolumn{1}{|c|}{ Crisis } & $\begin{array}{c}\text { Effect On Number } \\
\text { Of Tourists }\end{array}$ & $\begin{array}{c}\text { Effect on } \\
\text { Tourism Income }\end{array}$ \\
\hline $2010-2011$ & Revolution (2011) & $\mathbf{- 1 3 . 3 \%}$ & $\mathbf{- 8 , 6 \%}$ \\
\hline $2013-2014$ & Revolution (2013) & $\mathbf{- 8 . 2 \%}$ & $\mathbf{- 1 1 \%}$ \\
\hline $2015-2016$ & $\begin{array}{l}\text { Terrorist attack on board a } \\
\text { Russian plane (2015) }\end{array}$ & $\mathbf{- 3 4 . 8 \%}$ & $\mathbf{- 4 8 \%}$ \\
\hline $2019-2020$ & Covid-19 2020 & $\mathbf{- 5 8 , 6 \%}$ & $\mathbf{- 4 8 . 9 \%}$ \\
\hline
\end{tabular}

Source: Selim, Aidrous, \& Semenova (2020, p. 1150)

The previous table shows the important of moving towards Domestic Tourism to support the tourism industry in Egypt. In the meantime, the whole world has been facing the Covid-19 crisis in general and tourism in Egypt in particular. Due to the significance of Domestic Tourism and its benefits in Egypt's economy, the Tourism Government associations used many tools to promote the Domestic Tourism in Egypt. In this concern, Atallah (2013) mentioned some prominent strategies that Egyptian travel agencies and Tourism Government associations adopted include: using Smart and digital channels such as websites, social media pages, and mobile apps to promote and increase the tourist awareness for domestic people. Finally, it can be said that using and applying Smart Marketing tools in tourism industry is a vital element to promote tourism industry in general and Domestic Tourism in particular.

\section{Research Methodology}

This Study aims to identify the Smart Marketing methods, and explore the opportunities and challenges of using Smart Marketing methods in Domestic Tourism in Egypt. Thereby, it is based on a descriptive methodology which is popular in business research. Descriptive research is very common in the leisure area (Veal, 2006) as it combines mixed approaches represented in a questionnaire as a quantitative methodology. Creswell (2014) illustrated the Mixed methods of research as an approach which involving collecting both quantitative and qualitative data and integrating both of these forms. The main objectives of using this form to understanding the research problem more than either approach alone.

The questionnaire is the common data collection in leisure and tourism sector. It also is most suitable method for data collection from large samples and it is considered as a useful instrument to reach for some people who are not easy to approach (Kothari, 2004). It has been developed depended on the variables that were identified in the frame of reference, and also the previous studies which were mentioned in literature review (Shehawy, 2010; Kotler, Merino, Pintado, \& Juan, 2011; Armstrong, Nunkoo \& Ramkissoon, 2013; Guttormsdóttir, 2013; Mohamed, 2015; Yasmin, Tasneem, \& Fatema, 2015; Veleva \& Tsvetanova, 2020). It has been distributed to domestic tourists who have experience in using Smart marketing methods in their trips from April until June 2021. The questionnaire has been designed into online form, and distributed across different ways such as; Whats-app, emails, Facebook messenger, travel associations Facebook pages, travel agencies Facebook pages, popular Facebook communities, twitter pages and LinkedIn etc.

The questionnaire has been also directed to domestic tourists in Egypt. It is distributed in April until June 2021. As it is difficult to reach and distributed questionnaire for all of domestic tourists. Therefore, to withdraw a sample, the researcher determined the size of sample according the random simple sample method that clarified the size of random sample size is 385 (Krejcie \& Morgan, 1970, p.607610). A total of 606 completed forms of questionnaire distributed, answered and 
returned back. Then, the questionnaires were coded and entered into the computer to be analyzed by Statistical Package for Social Science (SPSS V.22).

On the other hand, the qualitative methodology is applied by conducting semistructured interviews with representatives or mangers of Top Ten Travel Agencies in Egypt 2019 according to Domestic Tourism market (Egyptian Ministry of Tourism and Antiquities, 2019). However, Only 7 of them completed the answers of all questions of the semi-structured interviews and 3 refused to respond. The interviews were conducted in June -July 2021 with marketing manager, IT manger, Tour leader, Excursion Manager and social media marketing representatives. In addition, the interviews were conducted only via the telephone. The average period of each interview ranged from 15 to 20 minutes. Each travel agency in discussions has a symbol to refer to its answers of interview questions as follows; (T1) for first travel agency, (T2) for second, and (T7) for last one.

The questionnaires forms have been coded and analyzed by Statistical Package for Social Science (SPSS V.22). The data has been analyzed using statistical methods such as; Frequencies, Percentages, Means, and Standard Deviation (SD): To describe the characteristics of the study population of the functional variables, and to determine the responses of its members towards the study axes. Cronbach's Alpha Test has been also used to calculate the stability coefficients of the questionnaire, and the coefficient of stability of each of the study axes. Moreover, the data of interviews was coded and analyzed as qualitative data forms through the content analysis.

This study determined the validity of the questionnaire and interviews sample questions using the Face validity as the scale was reviewed by five academic reviewers. The comments of the reviewers were done before implementing the field study. In order to measure the internal consistency and reliability of the study's constructs. Cronbach's Alpha $(\alpha)$ measure was used. The tests showed that the Reliability Coefficients for all the sections were equal 0.874 and Validity Coefficient for all the sections were equal 0.935 which indicates that the instrument is reliable for being used.

\section{Results and Discussion}

The following points declare the findings of the questionnaire and interviews:

\subsection{Domestic Tourism characteristics}

- The general travel purposes for the sample are, $89.8 \%$ of domestic tourists travel for Leisure Tourism, while $45.9 \%$ for Religion Tourism, and $44.9 \%$ for Conferences Tourism. It does mean the majority of domestic people in Egypt travel for leisure tourism.

- According to the number of annual Domestic Tours: $32 \%$ of domestic tourists travel for unlimited time, while $27.2 \%$ travel for one tour in the year, and $26.2 \%$ travel for Two Tours in the year. Therefore, these results declare that the domestic tourists in general like travel but the majority of them can't determine the annual rate or their domestic tours.

- According to average length of domestic tours: $49.5 \%$ of domestic tourists have spent on their previous domestic tours Three days, while $20.8 \%$ of them have spent more than three days. This clarifies that domestic people in Egypt prefer traveling in vacations. In addition, the most popular domestic tours programs duration (travel agencies offices or social media pages) are from 4 to 5 days. 
- The Majority of domestic people in Egypt prefer travelling with their families, whereas, $65.3 \%$ of them prefer travelling with Family and Relatives, while 27.1 prefer travelling with Friends.

Moreover, according to interviews results, all of Travel Agencies sample confirmed the importance of Domestic Tourism sector in the Egypt tourism market as they referred to the time of crisis when the Domestic Tourism is considered the savior or recover tool of tourism market in Egypt. However, in the normal time they interest in international tourism. T1, T2, T4 and T5 mentioned that the Domestic Tourism percentage versus international tourism ranged from 5 to $15 \%$ of their business.

Table (3): Domestic Tourism characteristics of respondents

\begin{tabular}{|l|c|c|}
\hline Purpose of domestic Travel & Frequency & $\begin{array}{c}\text { Percentage } \\
(\boldsymbol{\%})\end{array}$ \\
\hline Leisure Tourism & 544 & 89.8 \\
\hline Culture Tourism & 269 & 44.4 \\
\hline Medical Tourism & 34 & 5.6 \\
\hline Religion Tourism & 278 & 45.9 \\
\hline Convention Tourism & 272 & 44.9 \\
\hline Others & 6 & 1 \\
\hline Number of annual domestic tours & Frequency & Percentage \% \\
\hline one Tour & 165 & 27.2 \\
\hline Two Tours Total & 159 & 26.2 \\
\hline Three or more Total & 88 & 14.5 \\
\hline unlimited & 194 & 32.0 \\
\hline & $\mathbf{6 0 6}$ & $\mathbf{1 0 0 . 0}$ \\
\hline the average length of domestic tours & Frequency & Percentage \\
\hline One day & 99 & 16.3 \\
\hline Two days Total & 81 & 13.4 \\
\hline Three days & 300 & 49.5 \\
\hline More than three days & 126 & 20.8 \\
\hline & $\mathbf{6 0 6}$ & $\mathbf{1 0 0 . 0}$ \\
\hline Travel companion: & Frequency & Percentage \\
\hline Family and relatives & 396 & 65.3 \\
\hline Alone & 19 & 3.1 \\
\hline Friends & 164 & 27.1 \\
\hline Work colleagues & $\mathbf{6 0 6}$ & 4.5 \\
\hline & & $\mathbf{1 0 0 . 0}$ \\
\hline
\end{tabular}

\subsection{Challenges face the use of Smart Marketing methods in Searching and Booking Domestic Tours}

Concerning the challenges facing the use of Smart Marketing Methods in searching and booking Domestic Tours, they are stated in Table.4 in the following:

- The item "I don't believe or trust in online advertisements" ranked as first challenge with a mean and standard deviation (mean=3.20, standard deviation $=$ 0.864).

- "I am using other traditional tools in travel planning for domestic tours" ranked as second challenge with a mean and standard deviation (mean $=2.94, \quad$ standard deviation $=1.074$ ). 
- "I am not satisfying with online travel searching results" ranked as third challenge with a mean and standard deviation (mean=2.87, standard deviation $=$ 0.953).

- However, the item "I'm not an active user in social media sites and I haven't any Smart phone or tablet" ranked as last challenges with a mean (1.52) and the standard deviation was (0.848) compared to the mean and standard deviation of the total instrument.

Table (4): challenges that are facing Using Smart Marketing Methods

\begin{tabular}{|c|c|c|c|}
\hline Challenges & Mean & SD & 胥 \\
\hline I don't believe or trust in online advertisements & 3.20 & 0.864 & 1 \\
\hline $\begin{array}{l}\text { I am using other traditional tools in travel planning for } \\
\text { domestic tours }\end{array}$ & 2.94 & 1.074 & 2 \\
\hline I am not satisfied with online travel searching results & 2.87 & 0.953 & 3 \\
\hline $\begin{array}{l}\text { I take long time in searching for online travel Ads for } \\
\text { domestic tours }\end{array}$ & 2.70 & 0.948 & 4 \\
\hline $\begin{array}{l}\text { I have difficulty in connecting with travel agency online } \\
\text { and online information are not enough for domestic tours }\end{array}$ & 2.66 & 0.959 & 5 \\
\hline $\begin{array}{l}\text { There are not available variety of online travel Ads for } \\
\text { domestic tours }\end{array}$ & 2.65 & 0.995 & 6 \\
\hline I don't care if there are travel social media pages & 2.49 & 0.975 & 7 \\
\hline I don't know to use Internet & 2.01 & 1.058 & 8 \\
\hline $\begin{array}{l}\text { I don't active user in social media sites and I haven't any } \\
\text { Smart phone or tablet }\end{array}$ & 1.52 & 0.848 & 9 \\
\hline Total Mean & \multicolumn{3}{|c|}{2.56} \\
\hline
\end{tabular}

These results demonstrated that the E-Trust or untrusted in online services is the main challenge that is facing domestic tourists using Smart marketing application in tourism. The reason of these results may stem from the following points: (a) There are several fake or untrusted online information (i.e. advertisings, offers, pages and websites); (b) the culture of Smart or digital marketing in Egypt is still rarely in use despite the majority of domestic people have Smartphones and they are keen on using it. Therefore, the tourist insurance is one of the most important steps to great tourist etrust. There should be an organization to assure the tourist who books his trip through the Egyptian travel agencies website (Ezzat, Abd ElJalil, \& Othman, 2019). Meanwhile, the results of interview answers illustrate the following;

- The domestic tourist like traditional methods in booking their domestic tours.

- The domestic tourist hasn't trusted in online methods

- There are lacks in online awareness for domestic tourists.

- T1 and T5 stated that the best dealing way with domestic tourist is face to face.

These results achieve the Third objective of the research; "Determining the challenges or obstacles facing the use of Smart Marketing Methods in Domestic Tourism in Egypt". 


\subsection{Opportunities of Using Smart marketing Methods in Domestic Tourism in Egypt \\ a) Advantages of Smart Marketing Methods}

Table (5): Advantages of Smart Marketing Methods

\begin{tabular}{|c|c|c|c|}
\hline Advantages & Mean & SD & $\begin{array}{l}\overline{0} \\
\stackrel{0}{E}\end{array}$ \\
\hline $\begin{array}{l}\text { Allowing to customize the tour program ( nights and } \\
\text { optional tours) with offering many communication tools with } \\
\text { travel agency }\end{array}$ & 4.15 & 0.718 & 1 \\
\hline $\begin{array}{l}\text { Seeing as easy to use in searching for domestic tours and } \\
\text { allowing to compare prices of domestic tours ads }\end{array}$ & 4.12 & 0.815 & 2 \\
\hline $\begin{array}{l}\text { Offering domestic tours in attractive method more than } \\
\text { traditional tools in addition to Save time and effort }\end{array}$ & 4.08 & 0.834 & 3 \\
\hline $\begin{array}{l}\text { allowing to communicate with others, write comments, share } \\
\text { reviews on social media pages }\end{array}$ & 4.02 & 0.814 & 4 \\
\hline $\begin{array}{l}\text { Seeing as convenient method to book domestic tours and } \\
\text { providing unlimited information about domestic tours }\end{array}$ & 4.01 & 0.818 & 5 \\
\hline Total Mean & \multicolumn{3}{|c|}{4.08} \\
\hline
\end{tabular}

Table.5 shows the means and standard deviations of Advantages of Smart Marketing Methods. Where the means ranged between (4.15 - 4.01), "Allowing to customize the tour program (nights and optional tours) with offering many communication tools with travel agency" ranked as the first advantages with a mean and standard deviation (mean=4.15, standard deviation $=0.718$ ), and "Seeing as convenient method to book domestic tours and providing unlimited information about domestic tours" ranked the last advantages with a mean (4.01) and the standard deviation was (0.818).

In Travel Agencies Sector, according to the answers of travel agencies can summarize the advantages and disadvantages of using Smart marketing methods in Domestic Tourism as follows: Save time and effort (T1, T4, T5, T7), Easy use (T1, T4, T6), Not expensive (T1), Good tool to show pictures or videos about offers (T1, T3), Offer many tools for communication with tourists (T2, T3, T6), Offer many marketing tools (T2), Allow to enhance the marketing strategy (T3),Easy to reach to every home in Egypt (T4, T5), Availability in all time (T4), Allow to extend the market share of travel agency (T5), Allow to deal with more than one customer in the same time (T6) and finally Allow tourists to compare offers and choose the best (T7). All these advantages confirm that using Smart marketing methods in tourism is a vital part in enhancing or promoting Domestic Tourism in Egypt. 
b) Disadvantages of Smart Marketing Methods

Table (6): Disadvantages of Smart Marketing Methods

\begin{tabular}{|l|c|c|c|}
\hline \multicolumn{1}{|c|}{ Disadvantages } & Mean & SD & $\begin{array}{c}\text { 啳 } \\
\text { 芫 }\end{array}$ \\
\hline Some of online information is not updated & 3.41 & 0.929 & 1 \\
\hline $\begin{array}{l}\text { There are no completely security or privacy of personal data in } \\
\text { Smart Marketing methods }\end{array}$ & 3.38 & 1.029 & 2 \\
\hline $\begin{array}{l}\text { I am not trust in any online information particularly when pay } \\
\text { online and the large amount of offers make me puzzled or } \\
\text { confused }\end{array}$ & 3.31 & 0.934 & 3 \\
\hline There late in inquiries responses in Smart marketing methods & 3.17 & 0.918 & 4 \\
\hline Using Smart methods need specific skills & 3.07 & 1.022 & 5 \\
\hline \multicolumn{1}{|c|}{ Total Mean } & 3.27 & \\
\hline
\end{tabular}

The detailed examination of the results presented in Table.6 reveals the respondents' responses pertaining Disadvantages of Smart Marketing Methods. However, most of the items resulted with a slightly higher mean than 3 indicate the agreeableness of the respondents on those items, as imperative for Disadvantages of Smart Marketing Methods. The highest mean values for Disadvantages of Smart Marketing Methods emerged for the item "Some of online information isn't updated" (mean=3.41, standard deviation=0.929), followed by "There are no completely security or privacy of personal data in Smart Marketing Methods" (mean=3.38, standard deviation=1.029), whereas, the lowest mean value for this construct is for "Using Smart methods need specific skills" ( mean $=3.07$, standard deviation $=1.022$ ).

The answers of interviewees in this point have mentioned the following disadvantages: usually there are miscommunication between travel agency and domestic tourists (T1), No trust in online content (T2, T7), No trust in online payment (T2, T1), No trust in audiences (T2, T4), Purchase intention not clear (T3, T5), It is not suitable for all domestic tourists categories, It is considered only a tool for advertising and communication not to finish purchase order (T6).

\section{c. The current use of Smart Marketing methods in Domestic Tourism Market in Egypt}

The results of interviews in this point are presented in the following:

- Using Smart marketing tools in Travel Agencies: the answers of interviewers reveal that all travel agencies sample are using (website and Social Media) in their business. Only one travel agency has developed mobile app for its business (T1). Moreover, using Smart Marketing Methods in Travel Agencies needs more development. In addition, the COVID-19 pandemic may be a reason of the lack of development. However it leads more business sectors based in online methods in their business in this time. Concerning the Domestic Tourism, they have stated that using Smart marketing methods in Domestic Tourism is still limited. It can be restricted to advertising and communications tools only. Furthermore, many domestic tourists go directly to hotels without communication with travel agencies. Whereas (T1, T2, T5) have mentioned that they haven't use Smart marketing tools in Domestic Tourism as in international tourism, they depend on traditional strategies in Domestic Tourism.

- Effective Smart Marketing tool for Domestic Tourism in Egypt: All travel agencies have stated that "Facebook is the most effective tool for domestic tourist in Egypt". Therefore, social media is considered the main Smart Marketing tool 
that influence domestic tourists in Egypt. Moreover, these results illustrate the importance of social media especially Facebook in marketing strategies for Domestic Tourism. In addition, these answers supported that Facebook is the biggest social network worldwide. It is evident that the number of monthly active users reached 2.8 billion users and 10 million advertisers at the fourth quarter of 2020. As for Egypt, Facebook is the most popular social media platform with 38 million users in 2020 (Statista, 2021).

- Communication tools between Travel Agencies and Domestic Tourists: The interviewers confirmed that the domestic people depend on the following tools in communicating with travel agencies: phone calls, What's-App, Facebook messenger and SMS. Whereas T1 and T2 mentioned that they prefer using What'sapp or messenger in dealing with domestic tourists as they allow them take screenshots for messages.

These results achieve both the First objective "Identifying the Smart marketing application tools" and Second objective of the research "Exploring advantages and disadvantages of using Smart marketing methods in Domestic Tourism".

\section{Conclusion}

Smart Digital marketing proved its increasing and challenging growth, that is considered a future evolution of marketing, and it is changing the way which tourists engage with travel destinations. Moreover, mobile technology and Social networks (such as Facebook, Instagram and others) have the ability to support interaction between travel agencies and tourists that is guiding to a more personalized experience. Domestic Tourism in Egypt plays an important role in recovering the tourism market in Egypt. It is necessary to use Smart marketing methods in promoting Domestic Tourism in Egypt.

This paper provides an assessment for the use of Smart marketing methods in Domestic Tourism in Egypt. The methodology of this study depends on mixed approaches comprised of quantitative and qualitative tools. The quantitative and qualitative methods - represented in a questionnaire and semi-structured interviews to describe the opportunities and challenges of using Smart Marketing Methods in Domestic Tourism in Egypt. The sample of this study includes domestic Tourists and Top Ten of Travel Agencies in Egypt.

As for the main results of using the Smart Marketing Methods in Egypt, they are: The mistrust in online services is the main challenge that faces domestic tourists using Smart marketing application in tourism. In addition, the study highlighted the main disadvantages of using Smart Marketing Methods in Tourism. There are many opportunities to use Smart Marketing Methods in Domestic Tourism in Egypt such as: the use of Smart or Digital Marketing Methods offer many advantages for both domestic tourists and travel agencies in Egypt; Facebook is the most popular social media sites for domestic tourist in Egypt, majority of travel agencies samples are using (website and Social Media) in their business in general, and it offers many communication tools between domestic tourists and travel agencies.

Based on both the literature review and the field study findings, the following recommendations could be suggested:

1. The Ministry of Tourism and Antiquities should develop formal and trusted online platform for Domestic Tourism offers and it should include all trusted travel agencies in Egypt. 
2. The Ministry of Tourism and Antiquities should make many initiatives that encourage Domestic Tourism in Egypt by using Smart Marketing Methods.

3. Travel agencies social media pages should include all needed information for domestic tourists such as price, duration, place, payment tool and communication tools.

4. Travel agencies in Egypt should develop mobile apps to offer and introduce their programs for domestic tourists.Linking Smart marketing methods which are used in travel to allow tourists to find all information in an easy way.

5. Travel Agencies should offer discounts when using their Smart Marketing Methods in booking domestic tours.

6. Moreover, there should be agreements between the Ministry of Tourism and Antiquities and the Ministry of Information Communication Technology to offer secure software for travel agencies in Egypt to secure their information in Smart marketing application.

\section{References}

Abedelhamid, M. (2010). The Role of Strategic Tourism Marketing in Enhancing the Competitiveness of North Upper Egypt Area, PhD thesis, Fayoum University, Faculty of Tourism and Hotels.

Atallah, N. (2013). The role of the Egyptian media in promoting domestic tourism in Egypt after the January 25 revolution. Journal of Association of Arab Universities for Tourism and Hospitality, 41-52.

Baglione, S. (2014). Are Smartphones a Smart Marketing Buy. International Journal of Business, Marketing, and Decision Sciences, 7, 19-31.

Boes, K., Buhalis, D., \& Inversini, A. (2015). Conceptualising smart tourism destination dimensions Information and communication technologies in tourism 2015 (pp. 391-403): Springer.

Buhalis, D. (2000). Marketing the competitive destination of the future. Tourism Management, 211: 97-116.

Buhalis, D., \& Amaranggana, A. (2013). Smart tourism destinations Information and communication technologies in tourism 2014 (pp. 553-564): Springer.

Buhalis, D., Licata, M. Cristina, \& Richer, p., (2002). The future of E-Tourism intermediaries, Tourism Management, 23(3), 207-220.

Choo, H. (2014). Domestic tourism. In J. Jafari \& H. Xiao (Eds.), Encyclopedia of Tourism (pp. 1-2). Cham: Springer International Publishing.

Daszkiewicz, M. (2015). Smart Marketing for Cities. Zeszyty Naukowe Uniwersytetu Szczecińskiego. Problemy Zarządzania, Finansów i Marketingu, 41, 263-276. doi: 10.18276/pzfm.2015.41/1-21

Dictionary online (2019). Retrieved from: https://www.dictionary.com/browse/smart, accessed (24 Dec. 2019).

ETC. (2012). New media trend watch - online travel market. Retrieved from: http://www.newmediatrendwatch.com/world-overview/91onlinetravelmarket?showall=1 (Accessed on: 15 March 2020). 
Ezzat, M., Abd ElJalil, S., \& Othman, A. (2019). The Role of Egyptian Travel Agencies' Websites in Increasing Tourist's Online Trust. International Journal of Tourism and Hospitality Management, 2(1), 108-125.

Gajdošík, T. (2018). Smart Tourism: Concepts and Insights from Central Europe. Czech Journal of Tourism, 7(1), 25-44.

Gretzel, U., Reino, S., Kopera, S., \& Koo, C. (2015). Smart tourism challenges. Journal of Tourism, 16(1), 41-47.

Gretzel, U., Werthner, H., Koo, C., \& Lamsfus, C. (2015). Conceptual foundations for understanding smart tourism ecosystems. Computers in Human Behavior, 50, 558-563.

Gurjar, P., Kaurav, R.., \& Thakur, K. (2019). Content Marketing: Concepts and Its Relevance in the Tourism Industry. Paper presented at the Proceedings of 10th International Conference on Digital Strategies for Organizational Success.

Gutiérrez, C., Garbajosa, J., Díaz, J., \& Yague, A. (2013). Providing a Consensus Definition for the Term "Smart Product".

Guttormsdóttir, D. (2013). Online Marketing \& Travel Agencies. Development stages of websites and the use of webmetrics.

Hanson, W. (2000). Principles of Internet Marketing. Cincinnati, Ohio, SouthWestern College Publishing

Harrison, C., Eckman, B., Hamilton, R., Hartswick, P., Kalagnanam, J., Paraszczak, J., \& Williams, P. (2010). Foundations for smarter cities. IBM Journal of Research and Development, 54(4), 1-16.

Hedlund, J. (2012). Smart city 2020: Technology and society in the modern city, Microsoft Services

Hunter, W., Chung, N., Gretzel, U., \& Koo, C. (2015). Constructivist research in smart tourism. Asia Pacific Journal of Information Systems, 25(1), 103118.

Januszewska, M., Jaremen, D., \& Nawrocka, E. (2015). The effects of the use of ICT by tourism enterprises. European Journal of Service Management, 16, 65-73. doi: 10.18276/smt.2015.16-07

Kalra, R., Kumar, K., Batra, S., \& Namrata. (2017). Smart market: A step towards digital India.

Kaur, G. (2017). The importance of digital marketing in the tourism industry,International Journal of Research-Granthaalayah, 5(6), 72.

Kulwal, N. (2020). How the travel industry benefits from affiliate marketing. online. Retrieved Feburary 12, 2021, from https://www.financialexpress.com/brandwagon/how- the-travel-industrybenefits-from-affiliate-marketing/1825923/

Malik, R. (2017). An Empirical Study of Digital Marketing and its Elements. IJSRST, 3, 715-718.

Marquardt, K. (2017). Smart Services - Characteristics, Challenges, Opportunities 
and Business Models.

Matura, P. (2018). Digital Marketing Mix Strategies in the Tourism Industry in Zimbabwe: A Masvingo Tourism Destination Perspective. International Journal of Engineering and Management Research (IJEMR), 8(6), 211219.

Mazimhaka, J. (2006). The potential impact of domestic tourism on Rwanda's tourism economy. University of the Witwatersrand Johannesburg.

Mohamed, H. (2015). Electronic Marketing as a Tool to Achieve a Competitive Advantage for the Egyptian Travel Agencies (Travel Agencies -A\|). $(\mathrm{PhD})$, Faculty of Tourism and Hotels, Fayoum University.

Nam, T. \& Pardo T. A. (2011). Conceptualizing smart city with dimensions of technology, people, and institutions, The Proceedings of the 12th Annual International Conference on Digital Government Research, Retrieved from,

https://intaaivn.org/images/cc/Urbanism/background\%20documents/dgo_2011_smart city.pdf

Oxford learner's dictionaries online (2019). Retrieved from https://www.oxfordlearnersdictionaries.com/definition/american_english/s $\underline{\text { mart_1 }}$, accessed (24 Dec. 2019).

Pan, B., Xiang, Z., Law, R., \& Fesenmaier, D. R. (2011). The dynamics of search engine marketing for tourist destinations. Journal of Travel Research, 50(4), 365-377.

Rasty, F., Chou, C.-J., \& Feiz, D. (2013). The impact of internet travel advertising design, tourists' attitude, and internet travel advertising effect on tourists' purchase intention: the moderating role of involvement. Journal of Travel \& Tourism Marketing, 30(5), 482-496.

Selim, M., Aidrous, I., \& Semenova, E. (2020). International tourism: Prospects for development in the post coronavirus world (egyptian example). International Journal of Management (IJM), 11(7).

Shehawy, Y. (2010). Using Communication and Information Technology in Tourism Marketing Intelligence, Doctoral Theses, Helwan University, Faculty of Tourism and Hotels, Egypt.

Simões, D., Barbosa, B., \& Filipe, S. (2019). Smart Marketing with the Internet of Things.

Statista.com. (2021). Facebook: number of monthly active users worldwide 20082020. Retrieved Feb 2, 2021, 2021, from https://www.statista.com/statistics/264810/number-of- monthly-activefacebook-users-worldwide/

Stokes, R. (2011). eMarketing: The essential guide to digital marketing: Quirk eMarketing.

Vanolo, A. (2014). Smartmentality: The smart city as disciplinary strategy, Urban Studies, 51(5), 883-898

Washburn, D., Sindhu, U., Balaouras, S., Dines, R., Hayes, N., \& Nelson, L. (2010). Helping CIOs Understand 'Smart City' Initiatives: Defining the 
Smart City, Its Drivers, and the Role of the CIO. Cambridge, MA.

Werthner, H., Alzua-Sorzabal, A., Cantoni, L., Dickinger, A., Gretzel, U., Jannach, D., Neidhardt, J., Pröll, B., Ricci, F. and Scaglione, M. (2015). Future research issues in IT and tourism. Information TechNology and Tourism, 15(1), 1-15

World Tourism Organization (UNWTO) (2008): International Recommendations for Tourism Statistics, Series M No. 83/Rev.1, New York.

Zygiaris, S. (2013). Smart city reference model: Assisting planners to conceptualize the building of smart city innovation ecosystems, Journal of the Knowledge Economy, 4(2), 217-231.

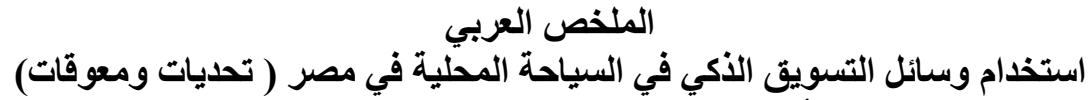

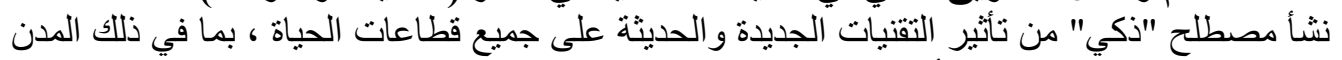

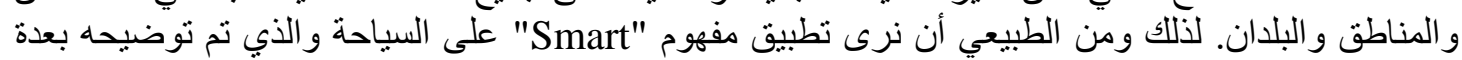

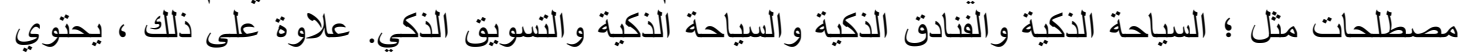

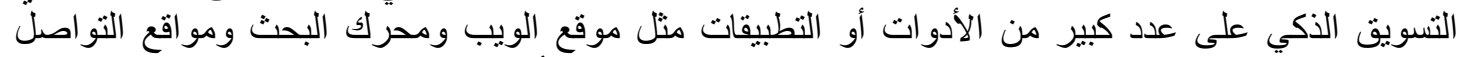

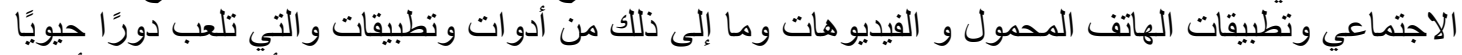

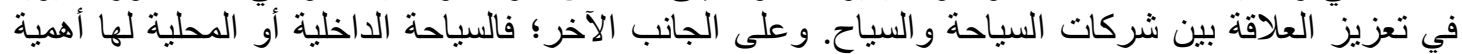

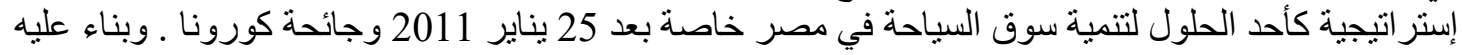

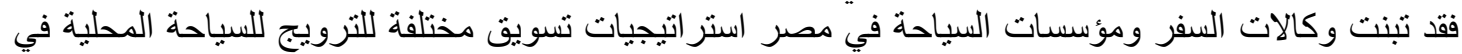

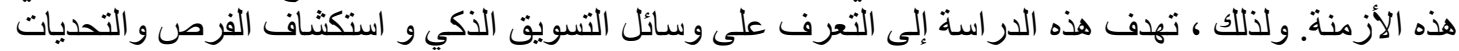

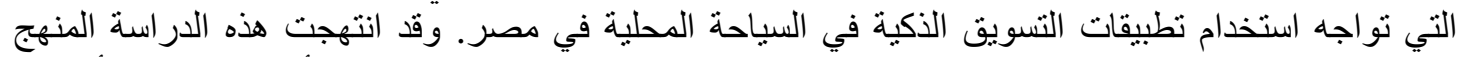

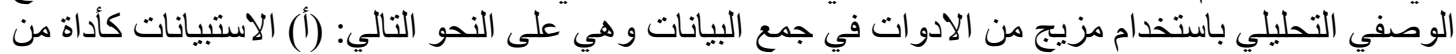

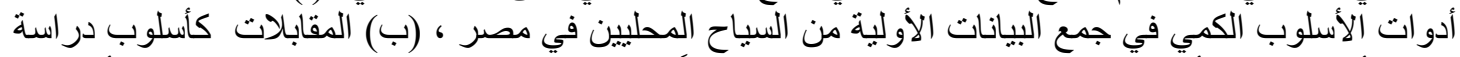

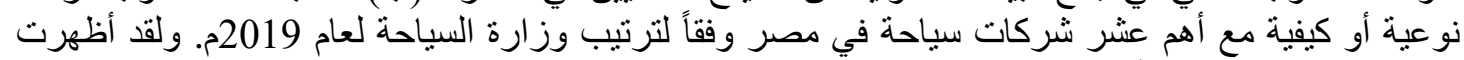

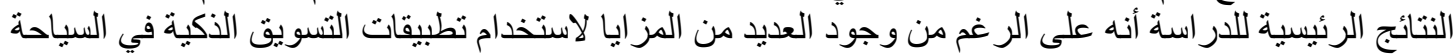

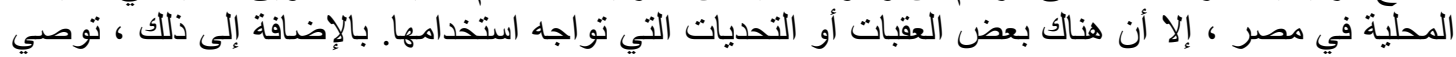

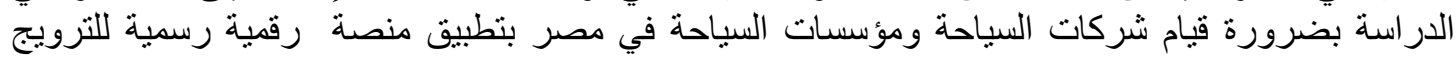

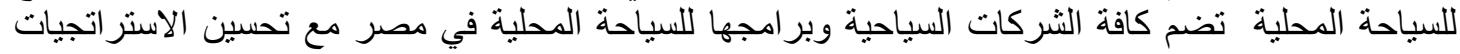
التسويقية لهم للاستفادة القصوى من استخدام تطبيقات التسويق الذكية في السياحة. 